STUDIA I PRACE WYDZIAŁU NAUK EKONOMICZNYCH I ZARZĄDZANIA nr 41, t. 2

\title{
Sławomir Lisek*
}

Uniwersytet Rolniczy w Krakowie

\section{WYKORZYSTANIE SYNTETYCZNEJ MIARY \\ SYTUACJI FINANSOWEJ PRZEDSIĘBIORSTWA W OCENIE SYTUACJI FINANSOWEJ GRUPY PRZEDSIĘBIORSTW}

\begin{abstract}
Streszczenie
Ważnym problemem są korzyści, jakie działalność przedsiębiorstw przynosi ich otoczeniu. Podmioty gospodarcze tworzące PKB, miejsca pracy pobudzające lokalną gospodarkę są ważnym ogniwem danego miasta, regionu, województwa czy kraju. Stan finansowy grupy przedsiębiorstw działających na danym terenie, obok kondycji poszczególnych przedsiębiorstw, powinien więc być przedmiotem zainteresowania polityków, mieszkańców, urzędników z danego terenu. W niniejszym artykule na podstawie danych empirycznych oceniono sytuację finansową pojedynczych przedsiębiorstw, a także podano różne warianty obliczenia syntetycznej miary sytuacji finansowej $m$ dla całej grupy przedsiębiorstw.
\end{abstract}

Słowa klucze: miara syntetyczna, wielowymiarowa analiza porównawcza, sytuacja finansowa grupy przedsiębiorstw

\section{Wprowadzenie}

O sytuacji gospodarczej danego kraju, regionu, województwa itp. w dużej mierze decyduje kondycja finansowa przedsiębiorstw tam działających, dlatego firmy odgrywają istotną rolę w rozwoju danego regionu. Sytuacja finansowa grupy przedsiębiorstw znajdujących się na danym terenie powinna być przedmiotem

* E-mail: k.w-s@wp.pl 
żywego zainteresowania zarówno mieszkańców, jak i osób podejmujących decyzje prawne, ekonomiczne i społeczne dotyczące danego terenu. Oprócz kondycji finansowej pojedynczych przedsiębiorstw należy badać stan ekonomiczny grupy przedsiębiorstw, dlatego uzasadniona wydaje się próba aplikacji miary syntetycznej przedsiębiorstwa do oceny finansowej grupy przedsiębiorstw traktowanych łącznie. Celem niniejszego artykułu jest zbadanie przydatności miary $m$ do oceny kondycji ekonomicznej zagregowanej grupy przedsiębiorstw. Należy pokazać, w jaki sposób właściwie obliczana miara $m$ może być przydatnym narzędziem w ocenie pozycji ekonomicznej grupy przedsiębiorstw traktowanej jako całość. Dane ekonomiczne wybrano z lat 2011, 2012 i nie aktualizowano ich, gdyż artykuł ma charakter metodologiczny. Jego celem jest wykazanie przydatności $m$ w ocenie kondycji grupy przedsiębiorstw, a nie konkretna ocena sytuacji przedsiębiorstw w ostatnich latach.

\section{Istota syntetycznej miary sytuacji finansowej przedsiębiorstwa m}

Syntetyczna miara sytuacji finansowej $m$ jest miernikiem syntetycznym skonstruowanym przez autora, służącym jednoznacznej i szybkiej ocenie sytuacji finansowej przedsiębiorstwa. W konstrukcji wykorzystuje wybrane diagnostyczne wskaźniki sytuacji finansowej przedsiębiorstwa, mianowicie:

- wypłacalność przedsiębiorstwa,

- rentowność kapitału własnego,

- rentowność netto majątku,

- płynność szybka (płynność finansowa II),

- zadłużenie kapitału własnego.

Powyższe wskaźniki wybrano do zbioru zmiennych diagnostycznych, wykorzystując taksonomiczne metody grupowania danych. Niniejsza miara może być obliczana w dwóch wariantach, dla potrzeb niniejszej publikacji zostanie obliczona według wzoru':

Konstrukcję tej miary opisano w publikacji autora niniejszego artykułu: Mierniki syntetyczne w procesie diagnozowania sytuacji finansowej przedsiębiorstwa, Zeszyty Naukowe Uniwersytetu Szczecińskiego nr 542, Wydawnictwo Naukowe Uniwersytetu Szczecińskego, Szczecin 2009, s. 263-270. Tam też podano sposób normalizacji i wielkości krytyczne użyte do normalizacji, czyli wielkości 0,$40 ; 0,05 ; 0,03 ; 1,00$; 1,2. Temu problemowi autor poświęcił też publikację: Wrażliwość miary syntetycznej na wielkości krytyczne wskaźników stużacych do jej budowy, Metody Ilościowe w Badaniach Ekonomicznych t. 15, nr 4, Wydawnictwo SGGW, Warszawa 2014, s. 71-79. 


$$
m=\frac{\frac{W p-0,40}{0,40}+\frac{R k w-0,05}{0,05}+\frac{R n m-0,03}{0,03}+\frac{Z t r-1,0}{1,00}+\frac{1,2-Z k w}{Z k w}}{5}
$$

gdzie:

$W p$ - wskaźnik wypłacalności przedsiębiorstwa;

$R k w$ - rentowność kapitału własnego;

Rnm-rentowność netto majątku;

Ztr - płynność szybka;

$Z k w$ - zadłużenie kapitału własnego ${ }^{2}$.

Sytuację przedsiębiorstwa ocenianą z wykorzystaniem tego wskaźnika uznaje się za korzystną, gdy obliczona dla niego miara syntetyczna jest większa od zera, natomiast w przeciwnym wypadku sytuację należy ocenić negatywnie. Gdy wartość $m$ jest równa zero, należy sytuację traktować jako neutralną̧3 W przypadku gdy dla danego przedsiębiorstwa jakiś wskaźnik nie jest możliwy do obliczenia (np. wskaźnik wypłacalności, gdy przedsiębiorstwo nie zaciągnęło, więc i nie musi spłacać kredytów), miarę tę należy obliczyć z pominięciem tego wskaźnika, odpowiednio pomniejszając mianownik.

\section{Grupa omawianych przedsiębiorstw}

Dla celów prezentacji możliwości wykorzystania proponowanej metody dla obliczenia kondycji finansowej grupy przedsiębiorstw dokonano wyboru metodą wylosowania sześciu spółek spośród tych notowanych na GPW, które nie są bankami, ubezpieczycielami, funduszami inwestycyjnymi ani biurami maklerskimi. Ponieważ celem pracy jest zobrazowanie metodologii, a nie dokonanie oceny kondycji jakiegoś regionu czy branży, reprezentatywność nie jest konieczna.

\section{Wawel SA}

Podstawowym przedmiotem działalności spółki według działów Polskiej Klasyfikacji Działalności jest produkcja kakao, czekolady i wyrobów cukierniczych. Akcje spółki znajdują się w obrocie na rynku podstawowym GPW w Warszawie.

2 Wskaźniki obliczane według wzorów: L. Bednarski, Analiza finansowa $w$ przedsiębiorstwie, PWE Warszawa 2007, s. 79, 85, 109, 114; Analiza ekonomiczna w przedsiębiorstwie, red. M. Jerzemowska, PWE Warszawa 2004, s. 138, 292-293; D. Wędzki, Analiza wskaźnikowa sprawozdania finansowego, Wolters Kluwer, Kraków 2006, s. 386.

3 O tym, jak wyciągać wnioski z ukształtowania się miary $m$, dokładniej podano w: S. Lisek, Mierniki syntetyczne w procesie diagnozowania..., s. 263-270. 
Według klasyfikacji przyjętej przez GPW spółka działa w sektorze przemysłu spożywczego. Czas trwania spółki jest nieoznaczony ${ }^{4}$.

\section{Graal SA}

Przedmiotem działalności gospodarczej spółki jest głównie przetwarzanie i konserwowanie ryb, skorupiaków i mięczaków. Czas trwania spółki zgodnie ze statutem jest nieograniczony ${ }^{5}$.

\section{Indykpol SA}

Czas trwania spółki jest nieograniczony. Podstawowym przedmiotem działania spółki jest:

- przetwarzanie i konserwowanie mięsa i drobiu;

- produkcja wyrobów z mięsa, włączając wyroby z mięsa drobiowego;

- chów i hodowla drobiu' 6 .

Dane tych spółek niezbędne do obliczenia miary syntetycznej przedstawiono w tabeli 1.

Tabela 1. Finansowe dane spółek Wawel, Graal, Indykpol

\begin{tabular}{|l|r|r|r|r|r|r|}
\hline \multicolumn{1}{|c|}{ Dane } & \multicolumn{2}{c|}{ Wawel } & \multicolumn{2}{c|}{ Graal } & \multicolumn{2}{c|}{ Indykpol } \\
\hline $\begin{array}{l}\text { Dane ekonomiczne } \\
\text { (tys. zł) }\end{array}$ & 2011 & 2012 & 2011 & 2012 & 2011 & 2012 \\
\hline Aktywa obrotowe & 186935 & 243779 & 145297 & 154046 & 229129 & 230946 \\
\hline Zapasy & 44859 & 38618 & 39985 & 36303 & 72141 & 90598 \\
\hline Aktywa razem & 378200 & 437625 & 378244 & 375090 & 462242 & 459480 \\
\hline Kapitał własny ogółem & 262828 & 312758 & 194533 & 204615 & 165076 & 160572 \\
\hline $\begin{array}{l}\text { Zobowiązania } \\
\text { długoterminowe }\end{array}$ & 1001 & 679 & 44215 & 24673 & 143333 & 82426 \\
\hline $\begin{array}{l}\text { Zobowiązania } \\
\text { krótkoterminowe }\end{array}$ & 94736 & 102856 & 139496 & 145802 & 153434 & 216098 \\
\hline $\begin{array}{l}\text { Zysk / (strata) netto za } \\
\text { okres }\end{array}$ & 56783 & 66668 & 1118 & 14980 & 8630 & -3318 \\
\hline Amortyzacja & 12109 & 14333 & 6354 & 6984 & 15238 & 16988 \\
\hline Rata kredytu & 0 & 0 & 94272 & 85400 & 17156 & 9486 \\
\hline Odsetki & 0 & 0 & 5390 & 6696 & 8620 & 11145 \\
\hline
\end{tabular}

Źródło: sprawozdania finansowe.

\footnotetext{
4 Raport giełdowy spółki, sprawozdanie finansowe za 2012 r. (Wawel).

5 Raport giełdowy spółki, sprawozdanie finansowe za 2012 r. (Graal).

6 Raport giełdowy spółki, sprawozdanie finansowe za 2012 r. (Indykpol).
} 


\section{Zakłady Przemysłu Cukierniczego „Mieszko” SA}

Podstawowym przedmiotem działalności ZPC „Mieszko” według rejestracji sądowej jest produkcja kakao, czekolady i wyrobów cukierniczych. Sektor według klasyfikacji Giełdy Papierów Wartościowych: spożywczy?

\section{Zakłady Automatyki „Polna” SA}

Przedmiotem działalności spółki jest:

- odlewnictwo metali,

- produkcja sprzętu i wyposażenia do napędu hydraulicznego i pneumatycznego,

- produkcja pozostałych pomp i sprężarek,

- produkcja pozostałych kurków i zaworów,

- obróbka i usuwanie odpadów innych niż niebezpieczne,

- odzysk surowców z materiałów segregowanych,

- sprzedaż hurtowa pozostałych maszyn i urządzeń,

- sprzedaż hurtowa niewyspecjalizowana,

- sprzedaż hurtowa odpadów i złomu.

Spółka zaliczana jest do branży przemysłu elektromaszynowego. Czas trwania działalności spółki jest nieoznaczony ${ }^{8}$.

\section{Apator SA}

Zgodnie ze statutem spółki podstawowym przedmiotem działalności jest działalność produkcyjna i usługowa w zakresie aparatury rozdzielczej i sterowniczej energii elektrycznej oraz sprzedaż aparatury i systemów pomiarowych. Akcje Apator notowane są na rynku podstawowym, sektor według klasyfikacji GPW w Warszawie - przemysł elektromaszynowy 9

Dane tych spółek niezbędne do obliczenia miary syntetycznej przedstawiono w tabeli 2 .

\footnotetext{
Raport giełdowy spółki, sprawozdanie finansowe za 2012 r. (Mieszko).

Raport giełdowy spółki, sprawozdanie finansowe za 2012 r. (Polna).

9 Raport giełdowy spółki, sprawozdanie finansowe za 2012 r. (Apator).
} 
Tabela 2. Finansowe dane spółek Mieszko, Polna, Apator

\begin{tabular}{|l|r|r|r|r|r|r|}
\hline \multicolumn{1}{|c|}{ Dane } & \multicolumn{2}{|c|}{ Mieszko } & \multicolumn{2}{c|}{ Polna } & \multicolumn{2}{c|}{ Apator } \\
\hline $\begin{array}{l}\text { Dane ekonomiczne } \\
\text { (tys. zł) }\end{array}$ & 2011 & 2012 & 2011 & 2012 & 2011 & 2012 \\
\hline Aktywa obrotowe & 131380 & 139975 & 17586 & 11780 & 68124 & 52306 \\
\hline Zapasy & 26377 & 27098 & 4890 & 4679 & 22289 & 18898 \\
\hline Aktywa razem & 413396 & 427178 & 43950 & 36708 & 256274 & 273799 \\
\hline Kapitał własny ogółem & 132515 & 136461 & 36851 & 29457 & 165192 & 199082 \\
\hline $\begin{array}{l}\text { Zobowiązania } \\
\text { długoterminowe }\end{array}$ & 178280 & 141985 & 3674 & 3715 & 21746 & 5609 \\
\hline $\begin{array}{l}\text { Zobowiązania } \\
\text { krótkoterminowe }\end{array}$ & 102601 & 148732 & 3425 & 3536 & 69336 & 69108 \\
\hline $\begin{array}{l}\text { Zysk / (strata) netto za } \\
\text { okres }\end{array}$ & 7989 & 3946 & 1612 & 2416 & 37731 & 70344 \\
\hline Amortyzacja & 10728 & 7485 & 2338 & 2421 & 5910 & 7192 \\
\hline Rata kredytu & 0 & 0 & 0 & 0 & 26000 & 41000 \\
\hline Odsetki & 6537 & 0 & 03 & 46 & 1674 & 2273 \\
\hline
\end{tabular}

Źródło: sprawozdania finansowe.

\section{Obliczenie niezbędnych wskaźników i miary syntetycznej dla poszczególnych przedsiębiorstw}

Dla przedsiębiorstw Wawel SA, Graal SA, Indykpol SA obliczono mierniki sytuacji finansowej i przedstawiono je w tabeli 3.

Tabela 3. Wskaźniki finansowe spółek Wawet, Graal, Indykpol

\begin{tabular}{|l|r|r|r|r|r|r|}
\hline \multirow{2}{*}{ Wskaźniki } & \multicolumn{2}{c|}{ Wawel } & \multicolumn{2}{c|}{ Graal } & \multicolumn{2}{c|}{ Indykpol } \\
\cline { 2 - 7 } & 2011 & 2012 & 2011 & 2012 & 2011 & 2012 \\
\hline Wypłacalność przedsiębiorstwa & $\mathrm{x}$ & $\mathrm{x}$ & 0,07 & 0,24 & 0,93 & 0,66 \\
\hline Rentowność kapitału własnego & 0,22 & 0,21 & 0,01 & 0,07 & 0,05 & $-0,02$ \\
\hline Rentowność netto majątku & 0,15 & 0,15 & 0,00 & 0,04 & 0,02 & $-0,01$ \\
\hline $\begin{array}{l}\text { Płynność szybka (płynność } \\
\text { finansowa II) }\end{array}$ & 1,50 & 1,99 & 0,75 & 0,81 & 1,02 & 0,65 \\
\hline Zadłużenie kapitału własnego & 0,36 & 0,33 & 0,94 & 0,83 & 1,80 & 1,86 \\
\hline Miara syntetyczna & 2,53 & 2,74 & $-0,51$ & 0,13 & 0,13 & $-0,54$ \\
\hline
\end{tabular}

Źródło: opracowanie własne.

Dla spółek ZPC Mieszko SA, Zakłady Automatyki „Polna” SA i Apator SA wskaźniki finansowe przedstawiono w tabeli 4. 
Tabela 4. Wskaźniki finansowe spółek Mieszko, Polna, Apator

\begin{tabular}{|l|c|c|c|c|c|c|}
\hline \multirow{2}{*}{\multicolumn{1}{|c|}{ Wskaźniki }} & \multicolumn{2}{c|}{ Mieszko } & \multicolumn{2}{c|}{ Polna } & \multicolumn{2}{c|}{ Apator } \\
\cline { 2 - 7 } & 2011 & 2012 & 2011 & 2012 & 2011 & 2012 \\
\hline Wypłacalność przedsiębiorstwa & 2,86 & 0,73 & $\mathrm{X}$ & $\mathrm{X}$ & 1,58 & 1,79 \\
\hline Rentowność kapitału własnego & 0,06 & 0,03 & 0,04 & 0,08 & 0,23 & 0,35 \\
\hline Rentowność netto majątku & 0,02 & 0,01 & 0,04 & 0,07 & 0,15 & 0,26 \\
\hline Płynność szybka (płynność finansowa II) & 1,02 & 0,76 & 3,71 & 2,01 & 0,66 & 0,48 \\
\hline Zadłużenie kapitału własnego & 2,12 & 2,13 & 0,19 & 0,25 & 0,55 & 0,38 \\
\hline Miara syntetyczna & 1,12 & $-0,19$ & 2,01 & 1,68 & 2,25 & 3,76 \\
\hline
\end{tabular}

Źródło: opracowanie własne.

Oceniając ogólnie za pomocą miary syntetycznej te przedsiębiorstwa, można wnioskować, że sytuacja ekonomiczna Wawel SA w badanym okresie jest dobra, natomiast w przypadku Graal SA i Indykpol SA sytuacja finansowa utrzymuje się na granicy neutralnej. Sytuacja finansowa ZPC „Mieszko” SA jednoznacznie dobra w 2011 roku, uległa znacznemu pogorszeniu w 2012 roku. Sytuacja finansowa zarówno Zakładów Automatyki „Polna” SA, jak i Apator SA jest dobra w obu badanych latach, jednak w przypadku Polna SA sytuacja w 2012 roku się pogorszyła, natomiast w przypadku Apator SA sytuacja w 2012 się polepszyła.

\section{Sposoby obliczania miary syntetycznej dla grupy przedsiębiorstw}

W przypadku próby obliczenia miary syntetycznej dla grupy przedsiębiorstw rodzą się wątpliwości co do sposobu, w jaki należy ją obliczać. Możliwe są co najmniej trzy podejścia do tego tematu. Pierwszy sposób to obliczanie miary syntetycznej na podstawie sumy wielkości wskaźników diagnostycznych poszczególnych przedsiębiorstw wchodzących w skład ocenianej grupy, czyli:

$$
m=\frac{\frac{\sum W p-l p * 0,40}{l p * 0,40}+\frac{\sum R k w-l p * 0,05}{l p * 0,05}+\frac{\sum R n m-l p * 0,03}{l p * 0,03}+\frac{\sum Z t r-l p}{l p}+\frac{l p * 1,2-\sum Z k w}{\sum Z k w}}{5}
$$

gdzie:

$\sum W p$ - suma wskaźnika wypłacalności przedsiębiorstwa;

$\sum R k w$ - suma wskaźnika rentowność kapitału własnego;

$\sum R n m$ - suma wskaźnika rentowność netto majątku;

$\sum Z t r$ - suma wskaźnika płynność szybka;

$\sum Z k w$ - suma wskaźnika zadłużenie kapitału własnego;

Ip - liczba przedsiębiorstw. 
Sposób ten ma swoje minusy. Do zasadniczych wad należy obliczanie tej miary z wykorzystaniem niekiedy skrajnie odstającej wartości wskaźników diagnostycznych (jako że są sumą poszczególnych wskaźników), a ponadto jeśli tylko dla jednego przedsiębiorstwa z ocenianej grupy któryś ze wskaźników nie jest możliwy do obliczenia, to miarę syntetyczną trzeba konstruować z pominięciem tego wskaźnika w ogóle, co zubaża informacje w niej zawarte. Jest to konieczne, ponieważ gdyby niektóre wskaźniki zsumować dla wszystkich przedsiębiorstw, a niektóre tylko dla części z nich, to wynik takiej operacji byłby zniekształcony. W sytuacji gdy należy pominąć jeden ze wskaźników, liczbę $5 \mathrm{w}$ mianowniku wzoru (2) należy zastąpić liczbą odpowiadającą liczbie wskaźników wykorzystanych do tworzenia miary syntetycznej (np. jeśli pominie się wypłacalność przedsiębiorstwa, liczbę 5 należy zastąpić liczbą 4). Dlatego obliczanie tej miary syntetycznej z wykorzystaniem powyżej opisanego sposobu nie wydaje się w pełni przydatne. Innym rozwiązaniem tego problemu jest obliczenie miary syntetycznej według wzoru (1) na podstawie wskaźników diagnostycznych będących średnimi arytmetycznymi ich wielkości dla poszczególnych przedsiębiorstw. Kolejnym sposobem jest obliczanie tej miary dla grupy przedsiębiorstw jako średniej arytmetycznej miar syntetycznych dla poszczególnych przedsiębiorstw. Ostatnie dwa sposoby wydają się o tyle lepsze, że zawierają w sobie możliwie pełną informację o sytuacji finansowej przedsiębiorstw.

\section{Obliczenie miary syntetycznej dla całej grupy omawianych przedsiębiorstw}

Obliczenie miary syntetycznej na podstawie wzoru (2) przedstawiono w tabeli 5.

Tabela 5. Suma wskaźników dla wszystkich przedsiębiorstw

\begin{tabular}{|l|c|c|}
\hline \multicolumn{1}{|c|}{ Suma wskaźników dla wszystkich przedsiębiorstw } & 2011 & 2012 \\
\hline Wypłacalność przedsiębiorstwa & $\mathrm{X}$ & $\mathrm{X}$ \\
\hline Rentowność kapitału własnego & 0,61 & 0,73 \\
\hline Rentowność netto majątku & 0,37 & 0,52 \\
\hline Płynność szybka (płynność finansowa II) & 8,67 & 6,70 \\
\hline Zadłużenie kapitału własnego & 5,97 & 5,78 \\
\hline Miara syntetyczna & 0,69 & 0,92 \\
\hline
\end{tabular}

Źródło: opracowanie własne.

Na podstawie tych obliczeń można stwierdzić, że sytuacja finansowa omawianej łącznie grupy przedsiębiorstw jest bardzo dobra, ponadto wyraźnie się polepszyła w 2012 roku. Jednak trzeba było pominąć całkowicie wskaźnik wypłacalności, 
ponieważ dla Wawel SA i Polna SA nie jest on możliwy do obliczenia (spółki te nie muszą spłacać kredytów). Naturalnie w mianowniku zamiast 5 należało przyjąć 4. Miara ta pozwala więc oceniać łącznie sytuację finansową grupy przedsiębiorstw, a także zmiany w niej zachodzące, natomiast może zawierać niepełną informację z powodu zubożenia o jeden wskaźnik, jak to ma miejsce $\mathrm{w}$ omawianym przypadku.

Miarę syntetyczną obliczono według wzoru (1) na podstawie mierników syntetycznych stanowiących średnią arytmetyczną wskaźników poszczególnych przedsiębiorstw. Przedstawiono ją w tabeli 6 .

Tabela 6. Miara syntetyczna obliczona na podstawie średnich arytmetycznych wskaźników diagnostycznych

\begin{tabular}{|l|c|c|}
\hline \multicolumn{1}{|c|}{ Średnia wartość wskaźników } & 2011 & 2012 \\
\hline Wypłacalność przedsiębiorstwa & 1,36 & 0,86 \\
\hline Rentowność kapitału własnego & 0,10 & 0,12 \\
\hline Rentowność netto majątku & 0,06 & 0,09 \\
\hline Płynność szybka (płynność finansowa II) & 1,44 & 1,12 \\
\hline Zadłużenie kapitału własnego & 1,00 & 0,96 \\
\hline Miara syntetyczna & 1,03 & 0,96 \\
\hline
\end{tabular}

Źródło: opracowanie własne.

Średnią wartość wskaźnika wypłacalności przedsiębiorstwa należy w tym przypadku obliczyć nie dla wszystkich szesciu, a dla czterech przedsiębiorstw, ponieważ w przypadku Wawel SA i Polna SA nie ma on sensu.

W omawianym przypadku można powiedzieć, że sytuacja finansowa omawianej łącznie grupy przedsiębiorstw jest pozytywna, praktycznie stała, niewielkie pogorszenie nastąpiło w 2012 roku. Miara ta pozwala więc ocenić kompleksowo sytuację finansową grupy przedsiębiorstw, a także zmiany w niej zachodzące. Uwzględnia wszystkie wskaźniki diagnostyczne, jakie można wyznaczyć, jednak wadą tej metody jest fakt, że średnia wskaźnika wypłacalności obliczana jest tylko dla czterech przedsiębiorstw, a średnie pozostałych wskaźników diagnostycznych są obliczane dla wszystkich przedsiębiorstw. Taki sposób obliczania wielkości będących podstawą miary syntetycznej budzi wątpliwości. 
Tabela 7. Miara syntetyczna obliczona jako średnia arytmetyczne miar syntetycznych dla poszczególnych przedsiębiorstw

\begin{tabular}{|l|c|c|}
\hline \multicolumn{1}{|c|}{ Przedsiębiorstwo } & Miara syntetyczna 2011 & Miara syntetyczna 2012 \\
\hline Wawel & 2,53 & 2,74 \\
\hline Graal & $-0,51$ & 0,13 \\
\hline Indykpol & 0,13 & $-0,54$ \\
\hline Mieszko & 1,12 & $-0,19$ \\
\hline Polna & 2,01 & 1,68 \\
\hline Apator & 2,25 & 3,76 \\
\hline Średnia miara syntetyczna & 1,25 & 1,26 \\
\hline
\end{tabular}

Źródło: opracowanie własne.

W tym przypadku - podobnie jak w analizie na podstawie tabeli 6 - można zauważyć, że sytuacja finansowa omawianej grupy przedsiębiorstw jest korzystna. Tutaj jednak nie uwidoczniają się zmiany w porównaniu do 2012 roku. Miara ta - podobnie jak zamieszczona $\mathrm{w}$ tabeli 6 - pozwala oceniać łącznie sytuację finansową grupy przedsiębiorstw, a także zmiany w niej zachodzące. Uwzględnia również wszystkie wskaźniki diagnostyczne, jakie daje się wyznaczyć.

Konkludując, stwierdzono, że miara syntetyczna jest wartą uwzględnienia propozycją do obliczania sytuacji grupy przedsiębiorstw łącznie, pozostaje natomiast do rozwiązania kwestia właściwego sposobu jej obliczania. Jednak wydaje się, że najlepsza jest średnia arytmetyczna miar pojedynczych przedsiębiorstw wchodzących w skład grupy. Wniosek ten jest oparty na podstawie, że sposób ten nie pomija żadnego wskaźnika, nie jest też bezpośrednio obciążony wadą, która dotyka miarę zbudowaną na bazie średnich wielkości wskaźników.

\section{Podsumowanie}

Miara syntetyczna sytuacji finansowej przedsiębiorstwa $m$ obok oceny sytuacji finansowej jednego przedsiębiorstwa może być wykorzystana do oceny sytuacji finansowej grupy przedsiębiorstw. Można z jej zastosowaniem badać sytuację przedsiębiorstw danej branży lub przedsiębiorstw znajdujących się w danym regionie, województwie czy kraju. By była maksymalnie użyteczna, należy ją obliczać w możliwie najlepszy sposób. Po przeprowadzeniu badania empirycznego wydaje się, że najlepszym sposobem obliczania tej miary dla grupy przedsiębiorstw jest średnia arytmetyczna miar $m$ dla poszczególnych przedsiębiorstw wchodzących w jej skład, ponieważ nie pomija żadnego wskaźnika i nie jest bezpośrednio obciążona wadą, która dotyka miarę $m$ obliczoną na podstawie średniej wielkości wskaźników diagnostycznych. 


\title{
Literatura
}

Analiza ekonomiczna w przedsiębiorstwie, red. M. Jerzemowska, PWE Warszawa 2004. Bednarski L., Analiza finansowa w przedsiębiorstwie, PWE, Warszawa 2007.

Lisek S. Mierniki syntetyczne w procesie diagnozowania sytuacji finansowej przedsiębiorstwa, Zeszyty Naukowe Uniwersytetu Szczecińskiego nr 542, Wydawnictwo Naukowe Uniwersytetu Szczecińskiego, Szczecin 2009, s. 263-270.

Lisek S., Wrażliwość miary syntetycznej na wielkości krytyczne wskaźników służacych do jej budowy, Metody Ilościowe w Badaniach Ekonomicznych t. 15, nr 4, 2014, Wydawnictwo SGGW, Warszawa 2014, s. 71-79.

Wędzki D., Analiza wskaźnikowa sprawozdania finansowego, Wolters Kluwer, Kraków 2006.

\section{APPLICATION OF THE SYNTHETIC MEASURE M IN THE PROCESS OF THE ECONOMICAL ANALYSIS GROUP OF ENTERPRISES}

\begin{abstract}
Very important problem is social responsibility of the business enterprises. Business companies creates GDB, demand of job, increases economy of local city, county, country and other region. From this reasons, companies are important part of local community. Financial situation of the group of enterprises, working in city, county, country or other region, is of local community's interest, as soon as financial condition of the separate company. In this article is depict how one can provide analysis financial situation of the enterprises, used $\mathrm{m}$ measure. And it was verified, based on the empiric data.
\end{abstract}

Translated by Stawomir Lisek

Keywords: financial situation of the enterprises, multivariate comparative analysis, synthetic measure

JEL codes: F21, F23 
